\title{
Model Team-Based Learning dan Model Problem-Based Learning Secara Daring Berpengaruh terhadap Kemampuan Berpikir Kritis Siswa
}

\section{Emy Dwi Nursulistyo ${ }^{1 *}$, Siswandari², Jaryanto ${ }^{3}$}

12 Universitas Sebelas Maret, Surakarta, Indonesia

*e-mail: Emi.dwi34@gmail.com

\begin{abstract}
Abstrak
Kemampuan berpikir kritis siswa rendah ditandai dengan siswa dalam memberikan penjelasan sederhana, mempertimbangkan kredibilitas sumber informasi dan memberikan alasan terhadap pengambilan keputusan sesuai dengan persoalan atau fenomena yang dihadapi masih kurang. Siswa kesulitan untuk mengidentifikasi, mempertimbangkan dan mengacu pada suatu asumsi. Penelitian ini merupakan jenis penelitian kuantitatif eksperimen. Penelitian ini merupakan jenis penelitian kuantitatif eksperimental. Populasi dalam penelitian ini adalah seluruh siswa kelas XI AKL SMKN I Karanganyar yang terdiri dari 105 siswa. Sampel yang digunakan adalah siswa kelas XI AKL I dan XI AKL III yang masing-masing berjumlah 35 siswa dengan menggunakan purposive sample berdasarkan nilai rata-rata pretest. Pengumpulan data menggunakan tes berbentuk essay. Data dianalisis dengan uji prasyarat analisis berupa uji normalitas dan uji homogenitas. Hasil penelitian menunjukkan bahwa terdapat perbedaan pengaruh penerapan model Team-Based Learning dan model Problem-Based Learning secara daring terhadap kemampuan berpikir kritis siswa dilihat melalui hasil pengujian Independent Sample T-Test yang menunjukkan kemampuan berpikir kritis siswa yang diajar menggunakan model Team-Based Learning memiliki rata-rata lebih tinggi 6,52 poin (rata-rata posttest) dibandingkan dengan model Problem-Based Learning yang dilakukan secara daring. Jadi dapat disimpulkan penerapan model Team-Based Learning lebih dapat meningkatkan kemampuan berpikir kritis siswa dibandingkan model Problem-Based Learning.
\end{abstract}

Kata kunci: team-based learning, problem-based learning, kemampuan berpikir kritis

\begin{abstract}
Students' low critical thinking skills are characterized by students in providing simple explanations, considering the credibility of information sources and providing reasons for decision making in accordance with the problem or phenomenon at hand. Students find it difficult to identify, consider and refer to an assumption. This research is a type of experimental quantitative research. This research is a type of experimental quantitative research. The population in this study were all students of class XI AKL SMKN I Karanganyar which consisted of 105 students. The sample used was the students of class XI AKL I and XI AKL III, each of which amounted to 35 students using a purposive sample based on the average pretest score. The data were collected using an essay-shaped test. The data were analyzed by means of the analysis prerequisite test in the form of a normality test and a homogeneity test. The results showed that there were differences in the effect of the application of the TeamBased Learning model and the online Problem-Based Learning model on students' critical thinking skills seen through the test results of the Independent Sample T-Test which showed the critical thinking skills of students who were taught using the TeamBased Learning model. The average posttest was 6.52 points higher than that of the online Problem-Based Learning model. So it can be concluded that the application of the Team-Based Learning model can improve students' critical thinking skills more than the Problem-Based Learning model.
\end{abstract}

Keywords: team-based learning, problem-based learning, critical thinking ability

\footnotetext{
*Corresponding author.

Received 30 Januari 2021; Accepted 1 Maret 2021; Available online 8 April 2021 (C) 2021 MI All Rights Reserved
} 


\section{Pendahuluan}

Revolusi industri 4.0 merupakan era terjadinya perubaan di bidang teknologi secara kompleks. Dunia kini memasuki perubahan era menjadi revolusi industri 4.0 untuk menjunjung teknologi sebagai basis kehidupan (Changwong, Sukkamart, \& Sisan, 2018). Perubahan berdampak pada dunia pendidikan. Kemajuan teknologi berdampak baik pada kemajuan dunia pendidikan. Pendidikan kini terfokus pada inovasi serta penggunaan perpaduan internet dan teknologi. Khususnya teknologi internet merupakan pilihan utama bagi dunia pendidikan untuk membantu proses pembelajaran (Oktavian \& Aldya, 2020; Wulandari, Sudatha, \& Simamora, 2020). Keunggulan dari teknologi internet terletak pada kecepatan untuk memperoleh informasi dan dapat digunakan pada segala situasi dan kondisi (Faslah, 2011; Suparni, 2016).

Situasi dan kondisi seperti pandemi covid-19 yang tidak memungkinkan untuk menyelenggarakan proses pembelajaran secara tatap muka. Pemerintah memberikan kebijakan untuk memberhentikan kegiatan pada seluruh lembaga khususnya sekolah sebagai salah satu upaya mencegah penularan covid-19 (Asmuni, 2020; Maulana \& Hamidi, 2020). Akibat pandemi tersebut proses pembelajaran tatap muka dialihkan menjadi pembelajaran secara daring (Fadlilah 2020; Wahyono, Husamah, and Budi 2020). Terciptanya teknologi dan aplikasi untuk menunjang kegiatan operasional individu dan kelompok, termasuk kegiatan belajar dan mengajar jarak jauh. Guru harus mampu merencanakan pembelajaran yang inovatif dengan memanfaatkan teknologi. Salah satu aplikasi untuk menunjang proses pembelajaran adalah google classroom. Aplikasi ini memungkinkan guru membuat kelas secara online untuk memberikan pengajaran dan berdiskusi bersama siswa (Yustianti, 2019).

Selain mengikuti perkembangan teknologi untuk menghadapi revolusi industri 4.0 bidang pendidikan harus mempersiapkan manusia yang mampu bersaing dan memiliki kualitas tinggi. Pendidikan harus membentuk keterampilan dan sikap individu abad ke-21. Keterampilan yang harus dimiliki agar mampu menghadapi persaingan revolusi industri adalah keterampilan 4C. Keterampilan 4C terdiri dari critical thinking and problem solving, creativity, communications skills and collaboration skills (Andrian \& Rusman, 2019; Fridanianti et al., 2018). Salah satu keterampilan dasar yang harus dimiliki adalah kemampuan berpikir kritis. Kemampuan berpikir kritis menjadi pilar perkembangan ekonomi pada abad ke-21 (Changwong, Sukkamart, and Sisan 2018: 40). Berpikir kritis merupakan kemampuan yang dapat dipelajari dan dilatihkan agar mampu memecahkan masalah secara efektif (Rahayuni, 2016). Keterampilan berpikir kritis digunakan untuk melakukan analisis permasalahan, memecahkan masalah, membuat keputusan dan memahami solusi atas permasalahan yang dihadapi (Fathiara, Badarudin, \& Muslim, 2019; Tuzlukova, Al-Busaidi, \& Burns, 2017). Kemampuan berpikir kritis dimiliki oleh siswa agar mampu berpikir tingkat tinggi terutama dalam memecahkan suatu permasalahan bertujuan untuk mengambil keputusan yang tepat dan logis untuk menyelesaikan maupun memecahkan permasalahan tersebut. Kemampuan berpikir kritis tidak dapat muncul begitu saja, namun perlu untuk diasah terus menerus, terutama mengasah sikap maupun perilaku yang menunjang seseorang untuk memiliki kemampuan berpikir kritis (Asriningtyas, 2018).

Berdasarkan uraian tersebut dapat disimpulkan bahwa kemampuan berpikir kritis merupakan kemampuan berpikir tingkat tinggi yang berguna untuk pemecahan masalah yang dapat dipengaruhi oleh faktor lingkungan. Kemampuan berpikir kritis termasuk pada ranah kognitif C4 sampai C6 yang mampu mengukur tingkat penguasaan yang meliputi menganalisis (analyzing), menilai (evaluating) dan mencipta (creating). Uraian dari taksonomi menurut Anderson dalam ranah kognitif C4 menganalisis merupakan kemampuan memisahkan suatu fakta atau konsep ke dalam beberapa komponen dan menghubungkan satu sama lain untuk memperoleh pemahaman atas konsep tersebut secara utuh. C5 mengevaluasi adalah kemampuan di dalam menunjukkan kelebihan dan kelemahan 
berdasarkan kriteria tertentu. C6 mencipta merupakan kemampuan ideal yang seharusnya dimiliki oleh seorang peserta didik setelah mempelajari kompetensi dengan kriteria tertentu.

Permasalahan yang terjadi saat ini masih banyak siswa yang memiliki kemampuan berpikir kritis yang rendah (Budiana, Sudana, \& Suwatra, 2013; Rosana, 2014). Permasalahan ini juga ditemukan pada salah satu sekolah dasar. Berdasarkan hasil observasi menunjukkan bahwa kemampuan berpikir kritis siswa kelas XI Akuntansi SMKN 1 Karanganyar masih rendah. Kemampuan siswa memberikan penjelasan sederhana seperti merumuskan pertanyaan atau menganalisis argumen masih kurang. Siswa belum mampu mempertimbangkan kredibilitas sumber informasi dan memberikan alasan terhadap pengambilan keputusan sesuai dengan persoalan atau fenomena yang dihadapi. Selain itu, siswa kesulitan untuk mengidentifikasi, mempertimbangkan dan mengacu pada suatu asumsi. Hal tersebut dikuatkan oleh perolehan skor kemampuan berpikir kritis siswa yang diperoleh melalui tes. Perolehan skor tes menunjukkan bahwa siswa kelas XI akuntansi SMKN 1 Karanganyar yang memiliki kemampuan berpikir kritis tinggi hanya 31\%, sementara yang menunjukkan kemampuan berpikir kritis rendah adalah 69\%. Skor yang dimaksud dapat dilihat pada Tabel 1.

Tabel 1. Perolehan skor pretest siswa kelas XI akuntansi

\begin{tabular}{ccc}
\hline Kelas & $\begin{array}{c}\text { Kemampuan Berpikir Kritis } \\
\text { Tinggi }(\%)\end{array}$ & $\begin{array}{c}\text { Kemampuan Berpikir Kritis } \\
\text { Rendah (\%) }\end{array}$ \\
\hline AKL 1 & 28 & 72 \\
AKL II & 38 & 62 \\
AKL III & 26 & 74 \\
\hline Rata-rata & $31 \%$ & $69 \%$ \\
\hline
\end{tabular}

Permasalahan dalam pembelajaran harus segera di atasi agar tercapainya tujuan pembelajaran. Melihat $69 \%$ siswa masih memiliki kemampuan berpikir kritis rendah, maka perlu dilakukan evaluasi pada proses pembelajaran agar dapat meningkatkan kemampuan berpikir kritis. Salah satu faktor yang menyebabkan kemampuan berpikir kritis siswa rendah adalah model dan metode pembelajaran yang kurang merangsang kemampuan berpikir kritis siswa yaitu dengan ceramah tanpa divariasi model pembelajaran lainnya. Guru memegang peran untuk merancang dan mengembangkan pembelajaran aktif yang berfokus pada kemampuan berpikir kritis siswa. Pembelajaran aktif tercermin pada teori kontruktivisme. Teori kontruktivisme mengharuskan siswa terlibat dalam pembelajaran secara aktif dan membangun konsep pembelajaran sendiri dan guru merupakan fasilitator (Christensen, Harrison, and Hollindale 2019: 4). Selain itu kemampuan berpikir kritis siswa dipengaruhi oleh lingkungan sekitar melalui kegiatan sosial yang tercermin pada teori kognitif sosial (Abdullah, Psikologi, \& Mercu, 2019; Suparni, 2016).

Pengembangan kemampuan berpikir kritis dapat dilakukan melalui pemilihan model pembelajaran yang tepat serta inovatif. Model pembelajaran yang bervariasi memudahkan guru untuk menyampaikan materi dan siswa merasa tertarik menerima materi pembelajaran sehingga dapat tercapainya tujuan pembelajaran. Model Team-Based Learning dan model Problem-Based Learning mampu merangsang kemampuan berpikir kritis siswa dalam pembelajaran melalui permasalahan dari guru selama proses pembelajaran (Christensen et al., 2019; Juraini, Taufik, \& Gunada, 2017). Odell (2018) menyatakan bahwa penerapan model Team-Based Learning mampu meningkatkan kemampuan berpikir kritis. Keterlibatan siswa secara aktif dalam pembelajaran mampu menciptakan pengalaman belajar yang lebih berarti. Penerapan model Team-Based Learning dapat merangsang siswa untuk menganalisis permasalahan yang diberikan guru agar siswa dapat menjawab dan memberi alasan. Model Team-Based Learning digunakan dalam kondisi siswa yang dituntut memahami informasi yang signifikan, menjawab pertanyaan komplek serta menyelesaikan permasalahan dan membantu siswa untuk bertanggung jawab dengan pribadinya bahwa pendapat yang dikatakan merupakan pendapat yang tepat dan dapat 
dipertanggungjawabkan (Dwirahayu, Kustiawati, \& Nurmala Nurmala, 2018; Heriyanti, 2018). Selain itu siswa mempunyai kesempatan lebih banyak untuk bekerjasama dan mengembangkan kemampuan berpikir kritis yang dimiliki untuk menyampaikan pendapat yang berasal dari pribadinya melalui buku atau teori yang telah dibaca, menganalisis permasalahan yang dihadapi bersama tim dan penyelesaian permasalahan.

Silva (2018) menyatakan model Problem-Based Learning adalah model yang memiliki strategi pengajaran aktif yang memungkinkan siswa untuk mengembangkan kemampuan berpikir kritis untuk memecahkan permasalahan melalui investigasi dan menganalisis permasalahan. Model Problem-Based Learning bertujuan mendorong siswa untuk menggunakan pengetahuan sebelumnya sebagai fokus pemecahan masalah dan membuat keputusan agar siswa lebih reflektif dan bertanggung jawab atas pengetahuan dirinya sendiri untuk meningkatkan kemampuan berpikir kritis. Hussin (2018) menyatakan bahwa Problem-Based Learning mampu meningkatkan kemampuan berpikir kritis siswa melalui strategi pengajaran. Guru memberikan ilustrasi permasalahan, siswa secara aktif melakukan analisis untuk penyelesaian masalah. Melalui permasalahan dari guru siswa dapat menarik kesimpulan.

Penelitian ini bertujuan untuk menguji pengaruh penerapan model Team-Based Learning sebagai model pembelajaran pada kelas eksperimen dan model pembelajaran Problem-Based Learning sebagai model pembelajaran yang diterapkan di kelas kontrol yang dilakukan secara daring untuk mengetahui pengaruh model pembelajaran terhadap kemampuan berpikir kritis siswa. Diharapkan model pembelajaran model Team-Based Learning dan Problem-Based Learning dapat meningkatkan kemampuan berpikir kritis pada siswa.

\section{Metode}

Penelitian ini merupakan jenis penelitian kuantitatif eksperimental. Secara khusus merupakan jenis penelitian eksperimen semu atau quasy eksperiment untuk mengetahui sebab akibat antara dua faktor yang sengaja ditimbulkan pada penelitian. Penelitian ini digunakan untuk menguji perbedaan pengaruh penerapan model pada kelas eksperimen dan kelas kontrol terhadap kemampuan berpikir kritis siswa yang dilakukan secara daring.

Penelitian ini dilaksanakan di SMKN 1 Karanganyar tahun ajaran 2020/2021 yang beralamat di Jl. Monginsidi Tegalgede, Karanganyar, Jawa Tengah. Waktu penelitian dilakukan pada tahun ajaran 2020/2021 pada semester genap. Penelitian terdiri dari empat tahap yaitu prapenelitian, perencanaan penelitian, pelaksanaan penelitian dan akhir penelitian. Prapenelitian berisi proses pengurusan izin, menentukan subjek dan objek penelitian dan menentukan kelas eksperimen serta kelas kontrol. Tahap kedua perencanaan penelitian teerdiri dari penyusunan RPP dan instrument penelitian. Tahap pelaksanaan penelitian dilaksanakan dengan mengadakan pretest, menyampaikan materi secara daring melalui aplikasi google classroom dengan menerapkan model Team-Based Learning pada kelas eksperimen dan model Problem-Based Learning pada kelas kontrol sesuai dengan RPP dan mengadakan posttest untuk mengukur kemampuan berpikir kritis siswa. Tahap akhir dalam penelitian ini berupa analisis data penelitian dan menyusun laporan akhir penelitian.

Populasi penelitian seluruh siswa kelas XI AKL SMKN 1 Karanganyar tahun ajaran 2020/2021 yang terdiri dari 105 siswa. Teknik pengambilan sampel menggunakan purposive sampling dengan memilih dua kelas yang memiliki karakteristik yang sama berdasarkan pada nilai rata-rata pretest untuk mengukur kemampuan awal siswa. Kelas XI AKL 1 dengan nilai rata-rata 40,72 dan 40,44 pada kelas XI AKL 3 yang masing-masing berjumlah 35 siswa. Kedua kelas tersebut memiliki nilai rata-rata pretest yang hampir sama sehingga peneliti memilih kedua kelas tersebut untuk digunakan sebagai penelitian. Pengumpulan data dalam penelitian menggunakan tes, observasi dan dokumentasi. Tes dilakukan dua kali yaitu pretest dan posttest untuk mengukur kemampuan berpikir kritis siswa yang dilakukan 
secara individu. Tes yang digunakan berbentuk uraian yang terdiri dari empat butir soal yang mencakup indikator berpikir kritis.

Instrumen utama yang digunakan adalah tes. Butir soal yang digunakan sudah melalui uji validitas dan reliabilitas instrumen, uji kesukaran soal dan uji daya pembeda soal diperoleh empat butir soal dinyatakan valid. Data dianalisis dengan uji prasyarat analisis berupa uji normalitas dan uji homogenitas yang menyatakan data berdistribusi normal (sig $\geq$ 0,05 ) dan bersifat homogen ( $\mathrm{sig}>0,05$ ). Data selanjutnya dianalisis melalui uji hipotesis dengan Independent sample T-Test dan Uji N-Gain berbantu program SPSS 21.

\section{Hasil dan Pembahasan}

Pengujian hipotesis menggunakan Independent sample T-Test brbantu program SPSS 21 diperoleh hasil perhitungan bahwa Sig. (2-tailed) $<0,05$, maka $\mathrm{H}_{1}$ diterima sehingga terdapat perbedaan pengaruh penerapan model Team-Based Learning dan model Problem-Based Learning terhadap kemampuan berpikir kritis siswa. Perhitungan nilai posttest kelas eksperimen dan kelas kontrol yaitu 83,77 poin dan 77,25 poin dengan hipotesis statistik $\mathrm{H}_{1}: \mu_{1} \neq \mu_{2}$. Hal tersebut menunjukkan bahwa penerapan model TeamBased Learning lebih baik dari pada model Problem-Based Learning secara daring terhadap kemampuan berpikir kritis siswa. Perhitungan N-Gain menunjukkan bahwa rata-rata kelas eksperimen sebesar 0,6450 sementara kelas kontrol 0,5843. Sehingga efektivitas model pembelajaan tersebut termasuk pada efektivitas sedang dengan kriteria $\mathrm{N}$-Gain $0,30<\mathrm{g}<0,70$ (Alfiah, Putra \& Subali 2018).

Berdasarkan hasil penelitian yang didapat, model Team-Based Learning dan Problem-Based Learning dapat meningkatkan kemampuan berpikir kritis siswa. Hal ini menunjukkan kemampuan berpikir kritis siswa dapat meningkat melalui penerapan model pembelajaran yang sesuai. Fakta menunjukkan bahwa masih digunakannya model pembelajaran yang kurang mendorong kemampuan berpikir kritis siswa. Hal tersebut dibuktikan dengan hasil pretest yang dibawah skor 60. Kemampuan berpikir kritis menjadi tolak ukur dalam perkembangan pemikiran siswa (Defiyanti \& Sumarni, 2019; Luzyawati, 2018). Kemampuan berpikir kritis dibutuhkan pada kehidupan nyata (Ikhsan, Munzir, \& Fitria, 2017; Putu et al., 2014). Sependapat dengan penelitian Yaldiz and Bailey (2019) bahwa kemampuan berpikir kritis mempersiapkan kemampuan siswa agar mampu menyelesaikan permasalahan nyata yang berkaitan dengan kehidupan. Kemampuan berpikir kritis dibutuhkan siswa untuk perkembangan pola pikir dan penyelesaian permasalahan pada kehidupan nyata (Jahro \& Ridho, 2015; Nur, Pujiastuti, \& Rahman, 2016). Hal ini karena adanya sikap bertanya dan mencari jawaban melalui pemikiran (Alfi, Sumarmi, \& Amirudin, 2016; Angriani, Bernard, Nur, \& Nurjawahirah, 2016). Inovasi dalam pembelajaran dapat berpengaruh pada kemampuan berpikir tingkat tinggi siswa (Nurhayati, Angraeni, \& Wahyudi, 2019). Pembelajaran yang mengacu pada teori kontruktivisme melahirkan inovasi pada pembelajaran aktif yang berorientasi pada siswa untuk mengontruksi pengetahuan (Waseso, 2018). Pembelajaran aktif dapat diterapkan melalui pengembangan model pembelajaran (Swanson, 2019).

Penelitian pada kelas eksperimen menerapkan model Team-Based Learning Selama proses diskusi siswa melakukan pertukaran informasi, klarifikasi pengetahuan awal yang dimiliki untuk memecahkan permasalahan. Pada proses diskusi guru menjadi fasilitator dengan mengontrol siswa. Siswa melakukan perbandingan masalah melalui pemaparan saat presentasi untuk mendapatkan umpan balik dari kelompok lain atau guru. Melalui proses pengklarifikasian pengetahuan saat diskusi dan pemberian umpan balik presentasi mengasah kemampuan berpikir kritis siswa. Hal itu sependapat dengan penelitian Haidet, Kubitz, and McCormack (2014) bahwa model Team-Based Learning dapat meningkatkan kemampuan berpikir kritis siswa melalui proses diskusi bersama tim membuat siswa merasa kegiatan pembelajaran lebih menantang, efektif dan menyenangkan. Permasalahan mendorong siswa untuk menyelesaikan dengan percaya diri dan persaingan berubah menjadi kerjasama serta semua anggota tim dituntut untuk berpikir kritis dan kreatif 
(Dwirahayu et al., 2018; Juraini et al., 2017). Siswa didorong untuk bertanggungjawab atas pengetahuannya sendiri dalam pembelajaran meskipun pembelajaran dilaksanakan berbasis tim (Michaelsen, Davidson, \& Major, 2014).

Penerapan model Problem-Based Learning secara daring berpengaruh terhadap kemampuan berpikir kritis siswa. Pembelajaran Problem-Based Learning yang efektif mampu meningkatkan kemampuan berpikir kritis (Marzuki \& Basariah, 2017; Silva et al., 2018). Peningkatan kemampuan berpikir kritis siswa melalui pembelajaran dengan model Problem-Based Learning dikarenakan siswa lebih termotivasi untuk mengikuti proses pembelajaran (Sumitro, Setyosari, 2017). Kegiatan diskusi dengan model Problem-Based Learning menciptakan pembelajaran aktif yang melibatkan siswa untuk mencari informasi dan bertukar pendapat dengan anggota kelompok untuk menyelesaikan permasalahan serta membentuk pengetahuan baru (Anjelina Putri, Swatra, \& Tegeh, 2018; Umbara, Sujana, \& Negara, 2020). Siswa melakukan refleksi serta evaluasi permasalahan dengan hasil diskusi kelompok yang akan dievaluasi oleh kelompok lain atau peneliti secara daring. Proses diskusi dan evaluasi tersebut membuat siswa mengembangkan kemampuan berpikir kritisnya. Kemampuan berpikir kritis siswa terbentuk dan terasah dari proses kerjasama atau diskusi dengan teman kelompok untuk memecahkan masalah. Model Problem-Based Learning menggunakan permasalahan yang berkaitan dengan disiplin ilmu, penyidikan autentik, kolaborasi dan memamerkan hasil karya (Haryati, 2017; Istiningrum, 2017). Siswa diberi kesempatan untuk bereksperimen dan merefleksi terkait hasil keputusan yang telah dibuat.

Model Team-Based Learning mengharuskan siswa untuk membaca buku terlebih dahulu sebelum pembelajaran, sehingga siswa sudah memiliki bekal kemampuan awal sebelum proses pembelajaran dimulai (Odell, 2018). Hal tersebut membuat pembelajaran dengan model Team-Based learning lebih dapat mengembangkan kemampuan berpikir kritis siswa melalui diskusi sebagai proses mengklarifikasi pengetahuan yang dapat meningkatkan kemampuan berpikir kritis siswa. Sedangkan model Problem-Based Learning menekankan permasalahan pada proses pembelajaran tanpa mengharuskan siswa memiliki kemampuan awal dari membaca materi. Tugas awal siswa adalah memutuskan pengetahuan yang perlu siswa kuasai melalui penelitian individu atau diskusi tim (Diah \& Riyanto, 2016; Michaelsen et al., 2014). Perbedaan penelitian ini dengan penelitian sebelumnya adalah penelitian sebelumnya oleh Michaelsen, Davidson \& Major (2014) meneliti perbedaan kemampuan berpikir kritis siswa pada universitas dengan membandingkan model pembelajaran konvensional, Team-Based Learning dan Problem-Based Learning. Sementara penelitian ini memfokuskan untuk menguji pengaruh model Team-Based Learning dan model ProblemBased Learning secara daring dan diterapkan di Sekolah menengah kejuruan akuntansi (SMK).

Hasil penelitian ini sejalan dengan teori kontruktivisme dan teori kognitif sosial yang diterapkan pada proses pembelajaran. Pembelajaran yang tercermin pada teori kontruktivisme dapat dituangkan melalui metode ataupun model pembelajaran. Penelitian ini membuktikan bahwa model Team-Based Learning berpengaruh lebih tinggi pada kemampuan berpikir kritis siswa dibandingkan model Problem-Based Learning pada pembelajaran praktikum akuntansi. Kemampuan berpikir kritis siswa dapat meningkat melalui kegiatan diskusi. Kegiatan ini termasuk kegiatan sosial untuk mencapai hasil pembelajaran tertentu (Abdullah, 2019). Model pembelajaran tersebut bermanfaat dalam upaya meningkatkan kemampuan berpikir kritis siswa. Hasil penelitian ini dapat diterapkan guru sebagai alternative dalam pembelajaran praktikum akuntansi atau mata pelajaran lain yang relevan.

\section{Simpulan}

Terdapat pengaruh penerapan model Team-Based Learning dan model ProblemBased Learning secara daring terhadap kemampuan berpikir kritis siswa. Hal ini menunjukkan bahwa model pembelajaran yang diterapkan dikelas berpengaruh pada 
kemampuan berpikir kritis siswa. Penerapan model Team-Based Learning lebih baik daripada model Problem-Based Learning dilihat.

\section{Daftar Pustaka}

Abdullah, S. M., Psikologi, F., \& Mercu, U. (2019). Social Cognitive Theory: https://doi.org/10.24167/psidim.v18i1.1708

Alfi, C., Sumarmi, S., \& Amirudin, A. (2016). Pengaruh Pembelajaran Geografi Berbasis Masalah Dengan Blended Learning Terhadap Kemampuan Berpikir Kritis Siswa SMA. Jurnal Pendidikan Teori, Penelitian, Dan Pengembangan, 4(1). https://doi.org/http://dx.doi.org/10.17977/jp.v1i4.6203

Alfiah, A. N., Putra, N. M. D., \& Subali, B. (2018). Media Scrapbook Sebagai Jurnal Refleksi untuk Meningkatkan Kemampuan Kognitif dan Regulasi Diri. Jurnal Pendidikan (Teori Dan Praktik), 3(1), 57. https://doi.org/10.26740/jp.v3n1.p57-67

Andrian, \& Rusman. (2019). Implementasi Pembelajaran Abad 21 Dalam Kurikulum 2013. Jurnal Penelitian IImu Pendidikan, 12(1). https://doi.org/https://doi.org/10.21831/jpipfip.v12i1.20116. 14-23

Angriani, A. D., Bernard, B., Nur, R., \& Nurjawahirah, N. (2016). Meningkatkan Kemampuan Pemecahan Masalah Melalui Pembelajaran Kooperatif Think-Talk-Write Pada Peserta Didik Kelas Viii1 Mtsn Model Makassar. MaPan: Jurnal Matematika Dan Pembelajaran, 4(1), 11-28. https://doi.org/10.24252/mapan.2016v4n1a2

Anjelina Putri, A. A., Swatra, I. W., \& Tegeh, I. M. (2018). Pengaruh Model Pembelajaran Pbl Berbantuan Media Gambar Terhadap Hasil Belajar Ipa Siswa Kelas lii Sd. Mimbar IImu, 23(1). https://doi.org/10.23887/mi.v23i1.16407

Asmuni, A. (2020). Problematika Pembelajaran Daring di Masa Pandemi Covid-19 dan

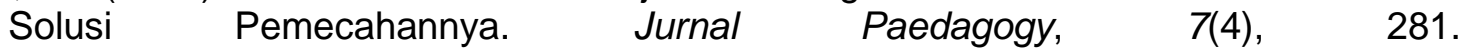
https://doi.org/10.33394/jp.v7i4.2941

Budiana, Sudana, \& Suwatra. (2013). Pengaruh Model Creative Problem Solving ( CPS ) Terhadap Kemampuan Berpikir Kritis Siswapada Mata Pelajaran IPA Siswa Kelas V SD. Mimbar PGSD Undiksha, https://doi.org/http://dx.doi.org/10.23887/jjpgsd.v1i1.816

Changwong, K., Sukkamart, A., \& Sisan, B. (2018). Critical thinking skill development: Analysis of a new learning management model for Thai high schools. Journal of International Studies, 11(2), 37-48. https://doi.org/10.14254/2071

Christensen, J., Harrison, J. L., \& Hollindale, J. (2019). Implementing team-based learning ( TBL ) in accounting courses. Accounting Education, $0(0), 1-25$. https://doi.org/10.1080/09639284.2018.1535986

Defiyanti, \& Sumarni. (2019). Analisis Kemampuan Berpikir Kritis Setelah Penerapan Problem Based Learning Berbantuan Lembar Kerja Peserta Didik Bermuatan Etnosains. Jurnal Phenomenon Pendidikan MIPA, 9(2), 206-218. https://doi.org/http://dx.doi.org/10.21580/phen.2019.9.2.4200

Diah, \& Riyanto. (2016). Problem-Based Learning Model In Biology Education Courses To Develop Inquiry Teaching Competency Of Preservice Teachers. Cakrawala Pendidikan, 35(1), 47-57. https://doi.org/https://doi.org/10.21831/cp.v1i1.8364

Dwirahayu, G., Kustiawati, D., \& Nurmala Nurmala. (2018). Team-Based Learning To Improve Students' Understanding Of Statistics. Jurnal Pengajaran MIPA, 23(1). https://doi.org/https://doi.org/10.18269/jpmipa.v23i1.11139

Fadlilah, A. N. (2020). Strategi Menghidupkan Motivasi Belajar Anak Usia Dini Selama 
Pandemi COVID-19 melalui Publikasi. Jurnal Obsesi: Jurnal Pendidikan Anak Usia Dini, 5(1), 373. https://doi.org/10.31004/obsesi.v5i1.548

Faslah, R. (2011). Pemanfaatan Internet Dalam Pengembangan Konsep Ips Dan Implikasinya Terhadap Pembelajaran Bermakna. Econosains Jurnal Online Ekonomi Dan Pendidikan, 9(2), 167-170. https://doi.org/10.21009/econosains.0092.07

Fathiara, A., Badarudin, B., \& Muslim, A. H. (2019). Meningkatkan Keterampilan Berpikir Kritis Dan Gemar Membaca Peserta Didik Melalui Model Predict Observe Explain Berbasis Literasi. Muallimuna: Jurnal Madrasah Ibtidaiyah, 4(2), 92-101. https://doi.org/10.31602/muallimuna.v4i2.1863

Fridanianti, A., Purwati, H., Hery Murtianto, Y., Kunci, K., Kritis, B., \& Kognitif, G. (2018). Analisis Kemampuan Berpikir Kritis Dalam Menyelesaikan Soal Aljabar Kelas VII SMP Negeri 2 Pangkah Ditinjau dari Gaya Kognitif Reflektif dan Kognitif Impulsif (Vol. 9).

Haidet, P., Kubitz, K., \& McCormack, W. T. (2014). Analysis of the Team-Based Learning Literature: TBL Comes of Age. Journal on Excellence in College Teaching, 25(3-4), 303-333. Retrieved from https://pubmed.ncbi.nlm.nih.gov/26568668/

Haryati, Y. (2017). Model Problem Based Learning Membangun Kemampuan Berpikir Kritis Siswa Sekolah Dasar. Jurnal Cakrawala Pendas, 3(2), 57-63. https://doi.org/http://dx.doi.org/10.31949/jcp.v3i2.596

Heriyanti, N. (2018). Peningkatan Prestasi Belajar Perbankan Dasar Melalui Penerapan Model Pembelajaran Team Based Learning. Jurnal Education and Economics, 1(3). Retrieved from http://jurnal.azharululum.sch.id/index.php/jee/article/view/20

Hussin, W. N. T. W., Harun, J., \& Shukor, N. A. (2018). Problem Based Learning to Enhance Students Critical Thinking Skill via Online Tools. Asian Social Science, 15(1), 14. https://doi.org/10.5539/ass.v15n1p14

Ikhsan, M., Munzir, S., \& Fitria, L. (2017). Kemampuan Berpikir Kritis dan Metakognisi Siswa Dalam Menyelesaikan Masalah Matematika Melalui Pendekatan Problem Solving. Jurnal Aksioma, 6(2) https://doi.org/http://dx.doi.org/10.24127/ajpm.v6i2.991

Islam, U., \& Walisongo, N. (2019). Formulasi Model Perkuliahan Daring Sebagai Upaya Menekan Disparitas Kualitas Perguruan Tinggi. 1(2), 151-160.

Istiningrum, A. A. (2017). Peningkatan Self-Regulated Learning Skills Mahasiswa Pada Mata Kuliah Akuntansi Pengantar Melalui Problem-Based Learning. Cakrawala Pendidikan, 36(1), https://doi.org/https://journal.uny.ac.id/index.php/cp/article/view/11080/pdf.

81-91.

Jahro, S., \& Ridho, D. (2015). Penerapan Model Problem Based Learning Menggunakan Media Exe Learning untuk Meningkatkan Hasil Belajar dan Kerjasama Siswa Pada Materi Hidrokarbon. Jurnal Pendidikan Kimia, 7(3), 80-86. https://doi.org/https://doi.org/10.24114/jpkim.v7i3.4261

Juraini, J., Taufik, M., \& Gunada, I. W. (2017). Pengaruh Model Pembelajaran Kooperatif Tipe STAD (Student Team Achievement Division) dengan Metode Eksperimen Terhadap Keterampilan Proses Sains dan Hasil Belajar Fisika pada Siswa SMA Negeri 1 Labuapi Tahun Pelajaran 2015/2016. Jurnal Pendidikan Fisika Dan Teknologi, 2(2). https://doi.org/10.29303/jpft.v2i2.293

Luzyawati, L. (2018). Analisis Kemampuan Berpikir Kritis Siswa Sma Materi Alat Indera Melalui Model Pembelajaran Inquiry Pictorial Riddle. Edu Sains: Jurnal Pendidikan Sains \& Matematika, 5(2), 9. https://doi.org/10.23971/eds.v5i2.732

Marzuki, \& Basariah. (2017). The Influence Of Problem-Based Learning And Project Citizen 
Model In The Civic Education Learning On Student'scritical Thinking Ability And Self Discipline. Cakrawala Pendidikan, 6(3), 382-400. Retrieved from https://journal.uny.ac.id/index.php/cp/article/view/14675/pdf.

Maulana, H. A., \& Hamidi, M. (2020). Persepsi Mahasiswa terhadap Pembelajaran Daring pada Mata Kuliah Praktik di Pendidikan Vokasi. Equilibrium: Jurnal Pendidikan, 8(2), 224-231. https://doi.org/10.26618/equilibrium.v8i2.3443

Mayona, E. L., \& Irawati, I. (n.d.). Penerapan Model Team Based Learning Pada Mata Kuliah Pengantar Pengelolaan Pembangunan kompetensi sendiri adalah kurikulum yang dalam proses menyusun struktur keterkaitan antar matakuliah untuk menghasilkan lulusan suatu program studi berbasiskan pada kem. (23), 254-266.

Michaelsen, L. K., Davidson, N., \& Major, C. H. (2014). Team-Based Learning Practices and Principles in Comparison With Cooperative Learning and Problem-Based Learning. Teaching in Higher Education, 25, 57-84. Retrieved from https://www.researchgate.net/journal/Teaching-in-Higher-Education-1470-1294

Michaelsen, L. K., \& Sweet, M. (2011). Team-Based Learning. (128), 41-51. https://doi.org/10.1002/tl

Nur, S., Pujiastuti, \& Rahman. (2016). Efektivitas Model Problem Based Learning (PBL) terhadap Hasil Belajar Mahasiswa Prodi Pendidikan Biologi Universitas Sulawesi Barat. Jurnal Saintifik, 2(2). https://doi.org/https://doi.org/10.31605/saintifik.v2i2.105

Nurhayati, N., Angraeni, L., \& Wahyudi, W. (2019). Pengaruh Model Problem Based Learning, Kemampuan Berpikir Kritis Terhadap Kemampuan Berpikir Tingkat Tinggi. EDUSAINS, 11(1), 12-20. https://doi.org/10.15408/es.v11i1.7464

Oktavian, R., \& Aldya, R. F. (2020). Efektivitas Pembelajaran Daring Terintegrasi di Era Pendidikan 4.0. Didaktis: Jurnal Pendidikan Dan IImu Pengetahuan, 20(2), 129-135. https://doi.org/10.30651/didaktis.v20i2.4763

Putu, N., Pramita, I., Raga, G., Riastini, P. N., Pendidikan, J., Sekolah, G., \& Ganesha, U. P. (2014). Pengaruh Model Experiential Learning Terhadap Keterampilan Berpikir Kritis IPA Kelas V Kecamatan Sukadana. E-Journal MIMBAR PGSD Universitas Pendidikan Ganesha, 2(1). https://doi.org/http://dx.doi.org/10.23887/jjpgsd.v2i1.2609

Rahayuni, G. (2016). Hubungan Keterampilan Berpikir Kritis Dan Literasi Sains Pada Pembelajaran Ipa Terpadu Dengan Model Pbm Dan Stm. Jurnal Penelitian Dan Pembelajaran IPA, 2(2), 131. https://doi.org/10.30870/jppi.v2i2.926

Rosana. (2014). Pengaruh Metode Pembelajaran dan Kemampuan Berpikir Kritis Terhadap Hasil Belajar Sejarah Siswa. Jurnal Pendidikan Sejarah, 3(1), 34-44. https://doi.org/http://dx.doi.org/10.30870/candrasangkala.v1i1.746

Silva, A. B. Da, Bispo, A. C. K. de A., Rodriguez, D. G., \& Vasquez, F. I. F. (2018). Problembased learning: A proposal for structuring $P B L$ and its implications for learning among students in an undergraduate management degree program. REGE Revista de Gestão, 25(2), 160-177. https://doi.org/10.1108/REGE-03-2018-030

Sumitro, A. H., Setyosari, P., \& Sumarmi. (2017). Penerapan Model Problem Based Learning meningkatkan Motivasi dan Hasil Belajar IPS. Jurnal Pendidikan:Teori, Penelitian, Dan Pengembangan, 12(1). https://doi.org/http://dx.doi.org/10.17977/jptpp.v2i9.9936

Suparni. (2016). Upaya Meningkatkan Kemampuan Berpikir Kritis Mahasiswa Menggunakan Bahan Ajar Berbasis Integrasi Interkoneksi. Jurnal Derivat: Jurnal Matematika Dan Pendidikan Matematika, 3(2). https://doi.org/10.31316/j.derivat.v3i2.716

Swanson, E., McCulley, L. V., Osman, D. J., Scammacca Lewis, N., \& Solis, M. (2019). The effect of team-based learning on content knowledge: A meta-analysis. Active Learning in Higher Education, 20(1), 39-50. 
https://doi.org/10.1177/1469787417731201

Tuzlukova, V., Al-Busaidi, S., \& Burns, S. L. (2017). Critical thinking in the language classroom: Teacher beliefs and methods Investigation of the Omani Foundation Program Students' Transitional Challenges: Focus on Computer Self-Efficacy and English Language Proficiency View project Teachers' Efficacy beli.

Umbara, I. A. A. P., Sujana, I. W., \& Negara, I. G. A. O. (2020). Model Pembelajaran Problem Based Learning Berbantuan Media Gambar Seri BerpengaruhTerhadap Kompetensi Pengetahuan IPS Siswa. Jurnal Mimbar IImu, 25(2), 13-25. https://doi.org/http://dx.doi.org/10.23887/mi.v25i2.25154

Wahyono, P., Husamah, H., \& Budi, A. S. (2020). Guru profesional di masa pandemi COVID19: Review implementasi, tantangan, dan solusi pembelajaran daring. Jurnal Pendidikan Profesi Guru, 1(1), 51-65. https://doi.org/https://doi.org/10.22219/jppg.v1i1.12462

Waseso, H. P. (2018). Kurikulum 2013 Dalam Prespektif Teori Pembelajaran Konstruktivisme. Ta'lim, 1(1), 59-72. https://doi.org/https://doi.org/10.29062/ta'lim.v1i1.632

Wulandari, Sudatha, \& Simamora. (2020). Pengembangan Pembelajaran Blended Pada Mata Kuliah Ahara Yoga Semester II di IHDN Denpasar. Jurnal Edutech Undiksha, 8(1), 1-15. https://doi.org/http://dx.doi.org/10.23887/jeu.v8i1.26459

Yaldiz, N., \& Bailey, M. (2019). The Effect of Critical Thinking on Making the Right Decisions in the New Venture Process. Procedia Computer Science, 158, 281-286. https://doi.org/10.1016/j.procs.2019.09.053 